\title{
Chromium(VI) Interaction with Plant and Animal Mitochondrial Bioenergetics: A Comparative Study
}

\author{
M. A. S. Fernandes, ${ }^{1}$ M. S. Santos, ${ }^{1}$ M. C. Alpoim, ${ }^{2}$ V. M. C. Madeira, ${ }^{2}$ \\ and J. A. F. Vicente ${ }^{3}$ \\ ${ }^{1}$ Departamento de Zoologia, Universidade de Coimbra, 3004-517 Coimbra, Portugal; E-mail: mfer@ci.uc.pt \\ ${ }^{2}$ Departamento de Bioquímica, Universidade de Coimbra, Apartado 3126, 3001-401 Coimbra, Portugal \\ ${ }^{3}$ Departamento de Botânica, Faculdade de Ciências, Universidade de Coimbra, 3000-393 Coimbra, Portugal
}

Received 10 December 2001; revised 19 February 2002; accepted 21 February 2002

\begin{abstract}
The mechanism of Cr(VI)-induced toxicity in plants and animals has been assessed for mitochondrial bioenergetics and membrane damage in turnip root and rat liver mitochondria. By using succinate as the respiratory substrate, $\mathrm{ADP} / \mathrm{O}$ and respiratory control ratio (RCR) were depressed as a function of $\mathrm{Cr}(\mathrm{VI})$ concentration. State 3 and uncoupled respiration were also depressed by $\mathrm{Cr}(\mathrm{VI})$. Rat mitochondria revealed a higher sensitivity to $\mathrm{Cr}(\mathrm{VI})$, as compared to turnip mitochondria. Rat mitochondrial state 4 respiration rate triplicated in contrast to negligible stimulation of turnip state 4 respiration. Chromium(VI) inhibited the activity of the NADH-ubiquinone oxidoreductase (complex I) from rat liver mitochondria and succinatedehydrogenases (complex II) from plant and animal mitochondria. In rat liver mitochondria, complex I was more sensitive to $\mathrm{Cr}(\mathrm{VI})$ than complex II. The activity of cytochrome $c$ oxidase (complex IV) was not sensitive to $\mathrm{Cr}(\mathrm{VI})$. Unique for plant mitochondria, exogenous NADH uncoupled respiration was unaffected by $\mathrm{Cr}(\mathrm{VI})$, indicating that the NADH dehydrogenase of the outer leaflet of the plant inner membrane, in addition to complexes III and IV, were insensitive to $\mathrm{Cr}(\mathrm{VI})$. The ATPase activity (complex V) was stimulated in rat liver mitochondria, but inhibited in turnip root mitochondria. In both, turnip and rat mitochondria, $\mathrm{Cr}(\mathrm{VI})$ depressed mitochondrial succinate-dependent transmembrane potential $(\Delta \psi)$ and phosphorylation efficiency, but it neither affected mitochondrial membrane permeabilization to protons $\left(\mathrm{H}^{+}\right)$nor induced membrane lipid peroxidation. However, $\mathrm{Cr}(\mathrm{VI})$ induced mitochondrial membrane permeabilization to $\mathrm{K}^{+}$, an
\end{abstract}

Correspondence to: M. A. S. Fernandes.

Contract Grant Sponsor: IMAR-Instituto do Mar, Universidade de Coimbra, Portugal.

Contract Grant Sponsor: Fundação para a Ciência e Tecnologia (FCT), Ministério da Ciência e da Tecnologia, Portugal.

Contract Grant Number: PBIC/C/BIO/1985/95.

(c) 2002 Wiley Periodicals, Inc. effect that was more pronounced in turnip root than in rat liver mitochondria. In conclusion, $\mathrm{Cr}(\mathrm{VI})$-induced perturbations of mitochondrial bioenergetics compromises energy-dependent biochemical processes and, therefore, may contribute to the basal mechanism underlying its toxic effects in plant and animal cells. (C) 2002 Wiley Periodicals, Inc. J Biochem Mol Toxicol 16:53-63, 2002; Published online in Wiley Interscience (www.interscience.wiley.com). DOI 10.1002/jbt.10025

KEYWORDS: Chromium; Mitochondria; Toxicity

\section{INTRODUCTION}

Chromium(VI), an environmental contaminant [1], is widely recognized to exert toxic effects towards humans [2], animals [3], and plants [4-6]. Although the mechanism of $\mathrm{Cr}(\mathrm{VI})$-induced toxicity is not clear, it is believed that oxidative stress plays an important role $[3,7]$. In animal cellular systems, reactive oxygen species (ROS) are generated through a Fenton-type redox cycling mechanism during the reduction process of $\mathrm{Cr}(\mathrm{VI})$, via reactive intermediates, e.g. $\mathrm{Cr}(\mathrm{V})$ and $\mathrm{Cr}(\mathrm{IV})$ to the more stable $\mathrm{Cr}(\mathrm{III})$. Through ROS-mediated reactions, $\mathrm{Cr}(\mathrm{VI})$ causes DNA and membrane damage, apoptosis, activation of the nuclear transcription factor (NF-kB), tumor supressor protein p53, cell growth arrest, and tyrosine phosphorylation [3,7-12]. In plants, reduction of $\mathrm{Cr}(\mathrm{VI})$ to $\mathrm{Cr}(\mathrm{V})$ was suggested to occur in roots [13] and leaves [14]. However, litle is known about the toxic effects of $\mathrm{Cr}(\mathrm{VI})$ in plant cells.

Mitochondria provide most of the cellular energy (ATP) and yield many intermediate compounds involved in normal cellular metabolism. Therefore, perturbations of mitochondrial function may result in severe consequences for general metabolism and all the 
energy transducing processes that require ATP [15]. A strong decrease in the ATP levels in cells exposed to $\mathrm{Cr}(\mathrm{VI})$ was detected in hamster fibroblasts [16,17], human gingival fibroblasts [18-21], and rat thymocytes [22]. This effect was closely correlated with the inhibition of cellular respiration in human and rat gingival fibroblasts and lymphocytes [16-19,23], as well as rat thymocytes and hepatocytes [22,24]. The inhibitory action of $\mathrm{Cr}(\mathrm{VI})$ on mitochondrial respiration was detected in isolated rat liver [22,24] and heart [25] mitochondria, and also in rat liver submitochondrial particles [26]. The mechanism by which $\mathrm{Cr}(\mathrm{VI})$ interfers with the mitochondrial bioenergetics was not clarified. It has been assigned to the oxidizing activity of $\mathrm{Cr}(\mathrm{VI})$, which shunts electrons from electron donors coupled to ATP production, and to the ability of $\mathrm{Cr}(\mathrm{III})$, derived from $\mathrm{Cr}(\mathrm{VI})$ reduction, to form stable complexes with ATP precursors and enzymes involved in the ATP synthesis $[16,17]$. Reduction of $\mathrm{Cr}(\mathrm{VI})$ has been suggested to occur at the expense of complex I [23,25,26], complex II $[19,27]$, and also complex IV [26] of the mitochondrial electron transport system, interfering with the electron flow $[19,23,25-27]$ and inducing the generation of hydroxyl radicals $(\cdot \mathrm{OH})$ via the Fenton-mechanism [28]. It is known that daily oral low-dose administration of $\mathrm{Cr}(\mathrm{VI})$ to rats results in enhanced lipid peroxidation in liver and brain mitochondria [29,30]. In plants, there are no studies concerning the influence of $\mathrm{Cr}(\mathrm{VI})$ on mitochondrial bioenergetics. Higher plant mitochondria are similar to animal counterparts in several aspects, yet they possess unique feactures, namely, the presence of specific NAD(P)H dehydrogenases, the size and complexity of DNA, higher rates of $\mathrm{O}_{2}$ consumption, oxidation of fatty acids, and an alternative oxidase [31,32].

To clarify the mechanism of $\mathrm{Cr}(\mathrm{VI})$-induced toxicity, the time and concentration-dependent effects of $\mathrm{Cr}(\mathrm{VI})$ on mitochondrial bioenergetics and membrane damage of mitochondria isolated from rat liver and turnip roots were examined. Mitochondrial bioenergetics was appraised by oxygen consumption, enzymatic activity of the respiratory complexes, mitochondrial transmembrane potential $(\Delta \Psi)$, and mitochondrial membrane permeabilization to $\mathrm{H}^{+}$and $\mathrm{K}^{+}$. Mitochondrial membrane damage by lipid peroxidation was examined by the assay of thiobarbituric acid reactive substances (TBARS) [33].

Turnip root mitochondria were used and compared with rat liver mitochondria because of the particular role of plant root and animal liver in cell detoxification mechanisms. Furthermore, turnip mitochondrial preparations are obtained with high degree of purity and intactness, as well as high respiratory activities and phosphorylation efficiency [34].

\section{MATERIALS AND METHODS}

\section{Preparation of Mitochondria}

Turnip root (Brassica napus, L.) mitochondria were prepared and purified in a $28 \%$ Percoll gradient as previously described [34] with small modifications. Briefly, turnip roots were peeled to expose clean tissue, washed in distilled water, homogenized in a juicer (Moulinex) at $2 \mathrm{~g}$ fresh weight per $\mathrm{mL}$ of cold homogenization medium (medium A) containing $250 \mathrm{mM}$ sucrose, $20 \mathrm{mM}$ HEPES ( $\mathrm{pH} 7.8$ ), $1 \mathrm{mM}$ EDTA, 0.1\% BSA, and $2 \mathrm{mM}$ cysteine (added just before homogenization), and filtrated through 4-6 layers of cheesecloth. The homogenate was centrifuged at $3,500 \times g$ for $15 \mathrm{~min}$ in a refrigerated centrifuge, and the supernatant fraction was centrifuged again at $10,000 \times g$ for $20 \mathrm{~min}$. The final pellet was resuspended and applied to a $22 \%$ Percoll gradient (containing $300 \mathrm{mM}$ mannitol plus $10 \mathrm{mM}$ HEPES, $\mathrm{pH}$ 7.2) and centrifuged for purification of the crude mitochondria. The mitochondrial fraction was collected from the Percoll gradient and washed twice and centrifuged at $30,000 \times g$ for 5 min in a washing medium (medium B) containing $250 \mathrm{mM}$ sucrose, $0.1 \mathrm{mM}$ EDTA, $0.1 \%$ BSA, and $10 \mathrm{mM}$ HEPES (pH 7.2). The pellets were gently resuspended in the washing medium at a protein concentration of 20 $30 \mathrm{mg} \mathrm{mL}^{-1}$.

Rat liver mitochondria were isolated from male Wistar rats (6 weeks) by differential centrifugation according to conventional methods [35]. After washing, the pellets were gently resuspended in the washing medium at a protein concentration of about $50 \mathrm{mg}$ $\mathrm{mL}^{-1}$.

Protein was determinated by the biuret method [36], using bovine serum albumin as the standard.

\section{Measurement of Respiratory Activities}

Oxygen consumption was monitored polarographically at $25^{\circ} \mathrm{C}$ with a Clark oxygen electrode, in a closed chamber with magnetic stirring. The reaction medium (medium C) consisted of $250 \mathrm{mM}$ sucrose, $10 \mathrm{mM}$ HEPES ( $\mathrm{pH}$ 7.2), $20 \mathrm{mM} \mathrm{KCl}, 5 \mathrm{mM}$ potassium phosphate, $2 \mathrm{mM} \mathrm{MgCl}$, and $0.1 \%$ BSA. Plant mitochondria (0.3-0.4 mg of protein) were incubated in 1.5 $\mathrm{mL}$ medium $\mathrm{C}$ supplemented with $0.2 \mathrm{mM}$ ATP (in the presence and absence of $\mathrm{K}_{2} \mathrm{Cr}_{2} \mathrm{O}_{7}$ ) for $5 \mathrm{~min}$, before energization with the respiratory substrates. Succinate $(10 \mathrm{mM})$, or $2 \mathrm{mM} \mathrm{NADH}$ or $30 \mathrm{mM}$ malate plus $0.5 \mathrm{mM}$ thiamine pyrophosphate (TPP) plus 0.5 $\mathrm{mM} \mathrm{NAD}{ }^{+}$were used. Animal mitochondria (1.0$1.5 \mathrm{mg}$ protein) were incubated in $1.5 \mathrm{~mL}$ reaction medium (in the presence and absence of $\mathrm{K}_{2} \mathrm{Cr}_{2} \mathrm{O}_{7}$ ) for 
$5 \mathrm{~min}$, before energization with $10 \mathrm{mM}$ succinate or $10 \mathrm{mM}$ malate plus $4 \mathrm{mM}$ glutamate. When the mitochondria were energized with succinate, rotenone $(2 \mu \mathrm{M})$ was added to the reaction medium. The respiratory control ratio (RCR) and ADP to oxygen ratio $(\mathrm{ADP} / \mathrm{O})$ were calculated according to the method used by Chance and Williams [37], considering that the saturation oxygen concentration was $250 \mathrm{nmol} \mathrm{O}_{2} / \mathrm{mL}$ in medium $\mathrm{C}$ at $25^{\circ} \mathrm{C}$. Uncoupled respiration was initiated by the addition of $1 \mu \mathrm{M}$ carbonyl cyanide $p$ trifluoromethoxyphenylhydrazone (FCCP).

Lower concentrations of mitochondrial protein were used in the assays performed with plant (0.2$0.3 \mathrm{mg} / \mathrm{mL})$ than with animal $(0.75-1.0 \mathrm{mg} / \mathrm{mL})$ mitochondria, taking into account the higher levels of purity, mitochondrial activities, and oxidative phosphorylation efficiency of turnip root mitochondrial preparations as compared with rat liver fractions [34].

\section{Measurement of Enzymatic Activities}

The NADH-ubiquinone oxidoreductase activity (complex I) was assayed spectrophotometrically at $25^{\circ} \mathrm{C}$ by following the oxidation of NADH as a decrease in absorbance at $340 \mathrm{~nm}$ [38]. The reaction was initiated by the addition of $150 \mu \mathrm{M} \mathrm{NADH}$ to $1 \mathrm{~mL}$ sample cuvette containing $20 \mathrm{mMK}_{2} \mathrm{HPO}_{4}(\mathrm{pH} 7.2), 8 \mathrm{mM} \mathrm{MgCl}_{2}$, $1 \mathrm{mM} \mathrm{KCN}, 0.25 \%$ BSA, $50 \mu \mathrm{M}$ dodecylubiquinone, used as an artificial electron acceptor, $0.75 \mathrm{mg}$ of broken rat liver mitochondria, with two cycles of freezing and thawing, and dichromate concentrations up to $100 \mu \mathrm{M}$. Control assays in the presence of $10 \mu \mathrm{M}$ rotenone were performed to ascertain that the NADH-ubiquinone oxidoreductase activity was being measured. In turnip mitochondria, the direct effect of $\mathrm{Cr}(\mathrm{VI})$ on NADHubiquinone oxidoreductase (complex I) was not evaluated because of the presence of other NADH oxidases [31].

The succinate dehydrogenase activity (complex II) was measured polarographically at $25^{\circ} \mathrm{C}$ in $1.5 \mathrm{~mL}$ of a reaction medium containing $250 \mathrm{mM}$ sucrose, $20 \mathrm{mM}$ $\mathrm{K}_{2} \mathrm{HPO}_{4}, 20 \mathrm{mM} \mathrm{KCl}, 5 \mathrm{mM} \mathrm{MgCl}, 10 \mathrm{mM}$ HEPES ( $\mathrm{pH}$ 7.7), and $0.05 \%$ BSA, as previously described [39] with some modifications. When the assays were performed using turnip root mitochondria $(0.3 \mathrm{mg})$, the reaction medium was supplemented with $0.2 \mathrm{mM}$ ATP. When the assays were performed using rat liver mitochondria $(1.5 \mathrm{mg})$, the reaction medium was supplemented with $2 \mu \mathrm{M}$ rotenone. Mitochondria were energized with $10 \mathrm{mM}$ succinate, and a phosphorylation with $100 \mu \mathrm{M}$ ADP was performed 2 min after energization. When state 4 was reached, $7.5 \mu \mathrm{g}$ antimycin $\mathrm{A}$ and $1 \mathrm{mM} \mathrm{KCN}$ were added. Five minutes after the addition of these inhibitors, the reaction was initiated by adding $1 \mathrm{mM}$ phenazine methasulfate (PMS), used as an artificial electron acceptor. Dichromate concentrations up to $1 \mathrm{mM}$ were added immediately after the addition of the inhibitors. The cytochrome $c$ oxidase activity (complex IV) was measured spectrophotometrically as described elsewhere [40] at $25^{\circ} \mathrm{C}$ by following the oxidation of reduced cytochrome $c$ as a decrease in absorbance at $550 \mathrm{~nm}$. The reaction was initiated by the addition of $30 \mu \mathrm{M}$ reduced cytochrome $c$ to a $1 \mathrm{~mL}$

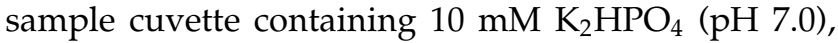
$50 \mu \mathrm{g}$ of broken mitochondria, $0.02 \%$ Triton X-100, and dichromate concentrations up to $1 \mathrm{mM}$. Controls in the presence of $1 \mathrm{mM} \mathrm{KCN}$ were performed to ascertain that the activity of the cytochrome $c$ oxidase was being measured.

The ATPase activity was determined by monitoring the inorganic phosphate $(\mathrm{Pi})$ yield in association with ATP hydrolysis. The reaction was carried out at $25^{\circ} \mathrm{C}$, in $1.5 \mathrm{~mL}$ of a reaction medium containing 130 $\mathrm{mM}$ sucrose, $50 \mathrm{mM} \mathrm{KCl}, 5 \mathrm{mM} \mathrm{MgCl} 2,0.5 \mathrm{mM}$ HEPES ( $\mathrm{pH}$ 7.2) in the presence and absence of $\mathrm{K}_{2} \mathrm{Cr}_{2} \mathrm{O}_{7}$ concentrations up to $1 \mathrm{mM}$. Broken mitochondria $(0.9 \mathrm{mg})$ were added to the reaction medium and incubated for $5 \mathrm{~min}$. The reaction was initiated by the addition of 2 $\mathrm{mM} \mathrm{Mg-ATP}$ and stopped $10 \mathrm{~min}$ after its initiation by the addition of $0.15 \mathrm{~mL}$ of ice-cold $40 \%$ trichloroacetic acid. Controls without Mg-ATP were carried out simultaneously. The samples and the controls were centrifuged at 2,000 $\times g$ and the supernatants were used for analysis of the Pi by the method of Taussky and Shorr [41].

\section{Estimation of Mitochondrial Transmembrane Potential}

The mitochondrial transmembrane potential $(\Delta \Psi)$ was estimated according to Kamo et al. [42]. Reactions were carried out in an open vessel at $25^{\circ} \mathrm{C}$, with magnetic stirring in $1.5 \mathrm{~mL}$ of respiration medium $\mathrm{C}$ supplemented with $3 \mu \mathrm{M} \mathrm{TPP}^{+}$.

\section{Mitochondrial Osmotic Swelling}

Mitochondrial osmotic swelling was monitored by detecting turbidity or pseudoabsorbance at $520 \mathrm{~nm}$ with a suitable spectrophotometer-recorder set up. Media were $44 \%$ iso-osmolar $(100 \%=270$ mosmolar $)$, containing $\mathrm{K}$ acetate $(54 \mathrm{mM})$ or $\mathrm{K}$ succinate $(54 \mathrm{mM})$ plus $5 \mathrm{mM}$ Hepes (pH 7.1), $0.1 \mathrm{mM}$ Tris-EGTA, and $0.2 \mathrm{mM}$ Tris-EDTA as previously described [43]. Turnip root mitochondria $(0.6 \mathrm{mg})$ or rat liver mitochondria $(1.5 \mathrm{mg})$ were suspended in $2.5 \mathrm{~mL}$ of medium supplemented with $0.1 \% \mathrm{BSA}$, at $25^{\circ} \mathrm{C}$, and the assays performed as described in the legends of the figures. 


\section{Measurement of Mitochondrial Membrane Lipid Peroxidation}

The measurement of mitochondrial membrane lipid peroxidation was performed for turnip root mirochondria $(0.3 \mathrm{mg})$ and rat liver mitochondria $(1.5 \mathrm{mg})$ with or without $1 \mathrm{mM} \mathrm{K}_{2} \mathrm{Cr}_{2} \mathrm{O}_{7}$ for $5,15,30$, and $60 \mathrm{~min}$ at $25^{\circ} \mathrm{C}$ in $1.5 \mathrm{~mL}$ of a reaction medium containing 125 $\mathrm{mM} \mathrm{KCl}, 10 \mathrm{mM}$ HEPES (pH 7.2), $5 \mathrm{mM} \mathrm{K}_{2} \mathrm{HPO}_{4}$, and $2 \mathrm{mM} \mathrm{MgCl}_{2}$.

When the assays were performed using rat liver mitochondria, the reaction medium was supplemented with $2 \mu \mathrm{M}$ rotenone. The levels of mitochondria membrane peroxidation were measured using $0.5 \mathrm{~mL}$ aliquots of mitochondria suspensions added to $0.5 \mathrm{~mL}$ of ice-cold $40 \%$ trichloroacetic acid. Then, $2 \mathrm{~mL}$ of $0.67 \%$ of aqueous thiobarbituric acid containing $0.01 \%$ of 2,6 di-tert-butyl- $p$-cresol was added. The mixtures were heated at $90^{\circ} \mathrm{C}$ for $15 \mathrm{~min}$, cooled in ice for $10 \mathrm{~min}$, and centrifuged at $850 \times g$ for $10 \mathrm{~min}$. The supernatant fractions were carefully removed and used for the assay of TBARS. TBARS were assayed spectrophotometrically at $530 \mathrm{~nm}$ as previously described [33].

\section{Chemicals}

All chemicals were obtained from Sigma (St Louis, $\mathrm{MO}$, USA) except dichromate $\left(\mathrm{K}_{2} \mathrm{Cr}_{2} \mathrm{O}_{7}\right)$ which was purchased from Ciba-Geigy (Basel, Switzerland).

Under the assay conditions ( $\mathrm{pH}>7)$ and dichromate concentrations below $10^{-1} \mathrm{M}$, dichromate depolymerises to chromate [Cr(VI)] anions [44], which readily cross the cell membranes and enter the cells [45]. Therefore, for a nominal concentration of dichromate, mitochondria were exposed to a $\mathrm{Cr}(\mathrm{VI})$ concentration twice the stated concentration of dichromate.

\section{Statistical Analysis}

All the experiments were performed using at least four to six repetitive independent mitochondrial preparations. The values are expressed as means \pm SE. The significance of the differences between the means was calculated by using the paired Student's $t$ test. Statistical significance was set at $p<0.05$.

\section{RESULTS}

\section{Effects of Dichromate on the Respiration of Turnip and Rat Mitochondria}

The effects of dichromate on succinate-dependent respiratory indexes, $\mathrm{RCR}$, and $\mathrm{ADP} / \mathrm{O}$ of turnip root and rat liver mitochondria, are shown in Figure 1.

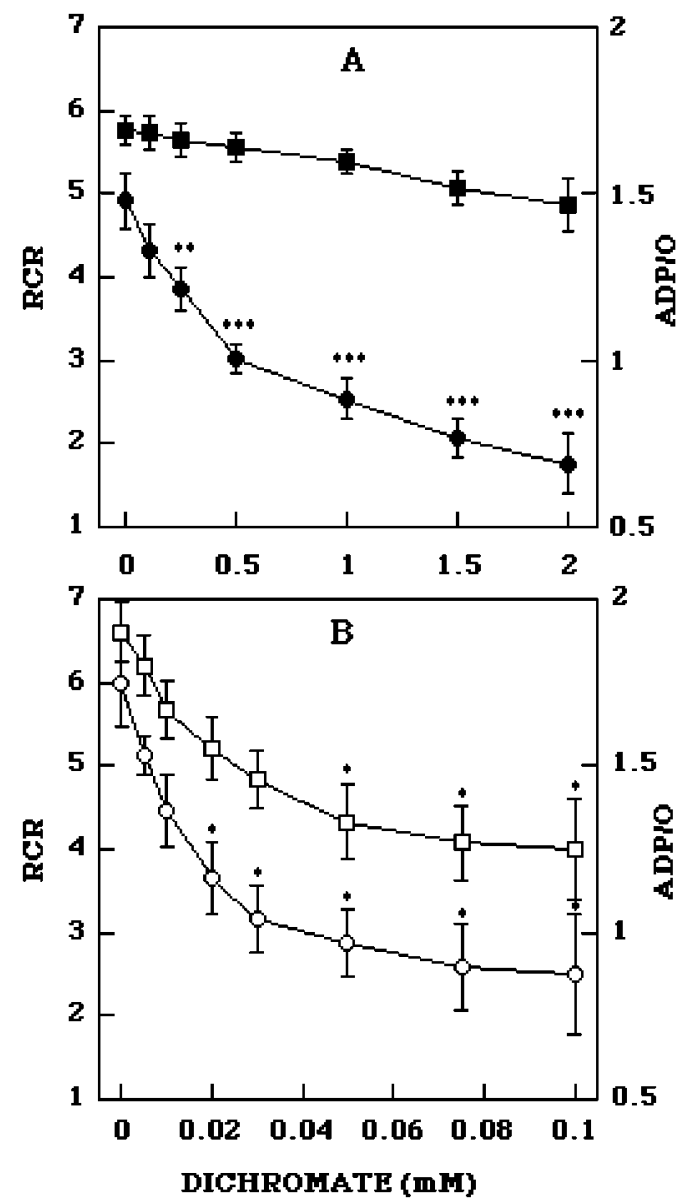

FIGURE 1. Effects of dichromate on succinate-dependent respiratory indexes RCR (circles), and ADP/O (squares) of (A) turnip root and (B) rat liver mitochondria. Control values for turnip root mitochondria are as follows: $\mathrm{RCR}=4.9 \pm 0.32$ and $\mathrm{ADP} / 0=1.3 \pm 0.03$; and control values for rat liver mitochondria are as follows: $\mathrm{RCR}=5.4 \pm$ 040 and $\mathrm{ADP} / 0$ ratio $=1.6 \pm 0.01$. The results correspond to mean $\pm \mathrm{SE}$ of four to six independent experiments. ${ }^{*} p<0.05,{ }^{* *} p<0.001$, and ${ }^{* * *} p<0.0001$ for paired $t$ test when compared with the control (in the absence of dichromate).

Dichromate, in the concentration range up to $2 \mathrm{mM}$, significantly depresses RCR, concomitantly reducing the $\mathrm{ADP} / \mathrm{O}$ ratio, in turnip root (Figure $1 \mathrm{~A}$ ). In rat liver mitochondria, the RCR and the ADP/O ratio were severely depressed by dichromate, at a lower concentration range (up to $100 \mu \mathrm{M}$ ) (Figure 1B).

Figure 2 shows the effects of dichromate on succinate-supported respiration of turnip and rat mitochondria. Preincubation of turnip root mitochondria with dichromate does not affect state 4 respiration (Figure 2A), but a strong stimulation occurs in rat liver mitochondria at concentrations up to $250 \mu \mathrm{M}$; above this point, inhibition is observed (Figure 2A). State 3 and uncoupled respirations were also inhibited, but rat liver mitochondria are more sensitive to dichromate as compared with turnip root mitochondria (Figure 2B). 

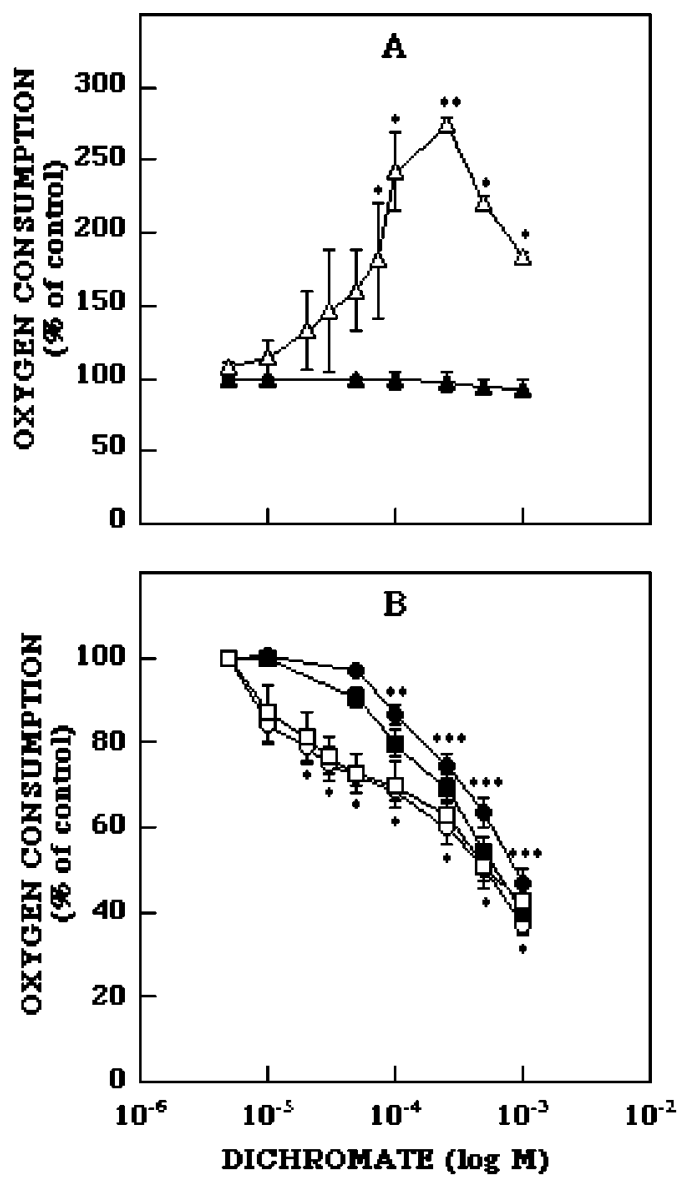

FIGURE 2. Effect of dichromate on succinate-supported $\mathrm{O}_{2}$ consumption in (A) state 4 , and (B) state 3 and uncoupled-respiration of turnip root (full symbols) and rat liver (open symbols) mitochondria. Control values for turnip root mitochondria are as follows: $(\boldsymbol{\Lambda})$ state $4=66.12 \pm 2.67,(\bullet)$ state $3=408.37 \pm 22.90$, and $(\boldsymbol{\square})$ uncoupled respiration $=389.69 \pm 59.58$; and control values for rat liver mitochondria are as follows: $(\triangle)$ state $4=13.6 \pm 2.9$, (o) state $3=68.35 \pm$ 9.72, and $(\square)$ uncoupled respiration $=83.83 \pm 10.11$, expressed in nmol $\mathrm{O}_{2}(\mathrm{mg} \text { protein })^{-1} \mathrm{~min}^{-1}$. The results correspond to mean $\pm \mathrm{SE}$ of four independent experiments (when the error bars are not visible SE is encompassed by the size of the symbols). ${ }^{*} p<0.05,{ }^{* *} p<0.001$, and ${ }^{* * *} p<0.0001$ for paired $t$ test when compared with the control (in the absence of dichromate).

Dichromate effects on turnip and rat uncoupledrespiration supported by malate/glutamate and succinate are given for comparison in Table 1. Uncoupledrespiration was inhibited in rat liver and turnip root mitochondria, at different concentration levels. Similar inhibitory values were reached in turnip with dichromate concentrations 10-fold higher as used in rat mitochondria assays. With malate/glutamate, stronger inhibitions were detected at dichromate concentrations significantly lower than those effective for succinate-supported respiration, suggesting that complex I is more sensitive to $\mathrm{Cr}(\mathrm{VI})$ toxicity than complex II.
TABLE 1. Effects of Dichromate on the UncoupledRespiration of Turnip Root and Rat Liver Mitochondria Supported by Malate and Succinate

\begin{tabular}{|c|c|c|c|c|}
\hline \multicolumn{5}{|c|}{ Oxygen Consumption (\% of control) } \\
\hline \multirow{2}{*}{$\begin{array}{l}\text { Dichromate } \\
(m M)\end{array}$} & \multicolumn{2}{|c|}{ Turnip Root Mitochondria } & \multicolumn{2}{|c|}{ Rat Liver Mitochondria } \\
\hline & Malate & Succinate & Malate & Succinate \\
\hline 0 & 100 & 100 & 100 & 100 \\
\hline 0.0050 & - & - & $66 \pm 7.3$ & $95 \pm 6.6$ \\
\hline 0.010 & - & - & $54 \pm 6.3$ & $87 \pm 6.7$ \\
\hline 0.025 & - & - & $40 \pm 3.7$ & $81 \pm 5.9$ \\
\hline 0.050 & - & - & $35 \pm 2.9$ & $73 \pm 4.8$ \\
\hline 0.075 & - & - & $28 \pm 4.7$ & $70 \pm 1.8$ \\
\hline 0.10 & $55 \pm 3.8$ & $80 \pm 3.2$ & $17 \pm 3.0$ & $70 \pm 5.4$ \\
\hline 0.25 & $46 \pm 6.8$ & $69 \pm 3.4$ & - & - \\
\hline 0.50 & $36 \pm 5.4$ & $59 \pm 2.7$ & - & - \\
\hline 1.0 & $21 \pm 2.6$ & $39.8 \pm 4.6$ & - & - \\
\hline
\end{tabular}

Assays were performed as described in the Material and Methods section. The results are expressed in percentage of control (\% of control). Control values, expressed as $\mathrm{nmol} \mathrm{O}_{2}$ consumed (mg protein) ${ }^{-1} \mathrm{~min}^{-1}$, in turnip root mitochondria are as follows: malate $=177 \pm 44$ and succinate $=389.7 \pm 59.8$. Control values in rat are as follows: malate $=22.4 \pm 5.6$ and succinate $=83.8$ \pm 10.1 .

The effects of dichromate on uncoupled-respiration supported by exogenous NADH, succinate or malate were studied in turnip root mitochondria, and the results are shown in Figure 3. Oxygen consumption rate with exogenous NADH was not affected by dichromate $(1 \mathrm{mM})$, but succinate and malate respiration were inhibited, with higher sensitivity for malate than for succinate. The data (above reported) for the $\mathrm{Cr}(\mathrm{VI})$ effects on rat liver mitochondria, namely, stimulation of state 4 respiration and inhibitions of state 3 and uncoupledrespiration supported by succinate, are quite consistent with previously published data [24].

\section{Effects of Dichromate on Enzymatic Activities and Mitochondrial ATPase}

The effects of dichromate on the enzymatic activities of respiratory complexes and ATPase (complex V) are shown in Figures 4A and 4B. Dichromate concentrations up to $1 \mathrm{mM}$ significantly decreased the activities of the NADH-ubiquinone oxidoreductase (complex I) for rat liver mitochondria and succinate dehydrogenases (complex II) for both tested mitochondria (Figure 4A). Succinate dehydrogenase is more sensitive to $\mathrm{Cr}(\mathrm{VI})$ in rat liver than in turnip root mitochondria (Figure 4A), whereas cytochrome $c$ oxidase (complex IV) was insensitive to $\mathrm{Cr}(\mathrm{VI})$ (Figure 4A). The insensitivity of NADHubiquinone oxidoreductase (complex I) of turnip mitochondria to $\mathrm{Cr}(\mathrm{VI})$ was not directly evaluated because of the presence of other NADH oxidases [31]. The insensitivity of ubiquinol-cytochrome $c$ reductase (complex III) to $\mathrm{Cr}(\mathrm{VI})$ of rat and turnip mitochondria was 
A

B

C

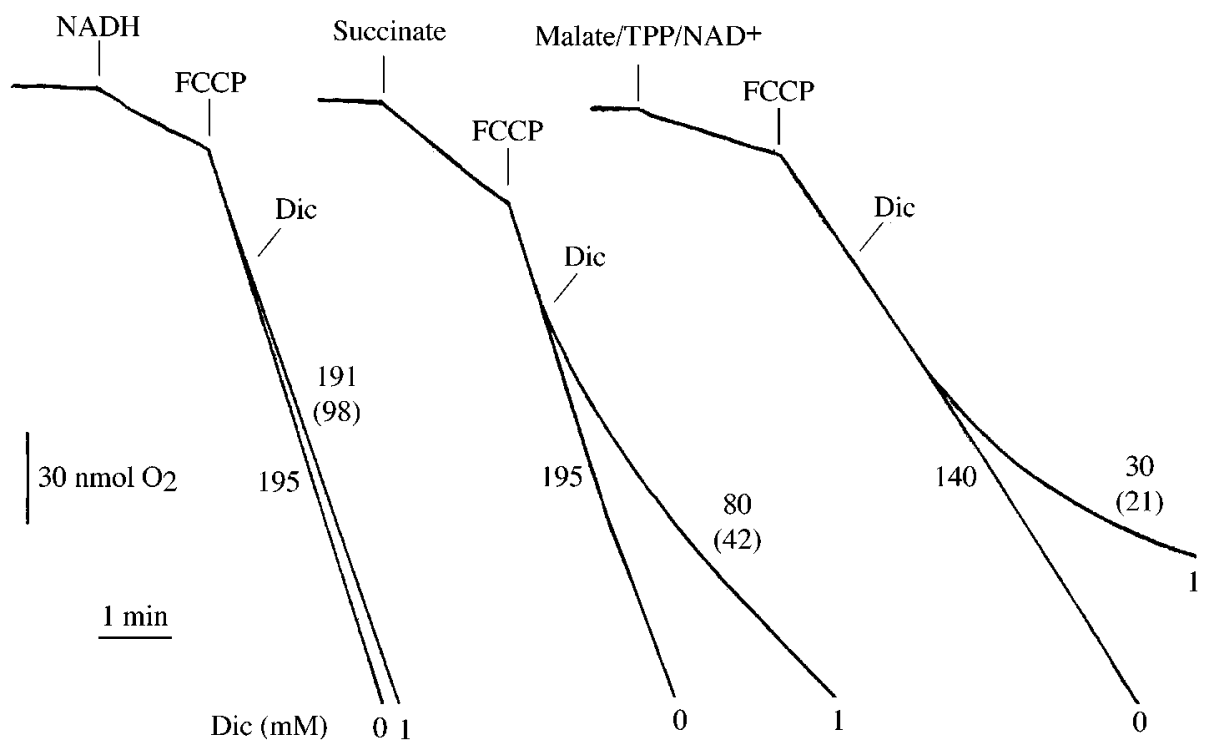

FIGURE 3. Oxygen consumption records of uncoupled-respiration from turnip root mitochondria respiring (A) exogenous NADH, (B) succinate or $(\mathrm{C})$ malate/TPP/NAD ${ }^{+}$. Numbers on records are values of activities with exogenous NADH, succinate, and malate/TPP/NAD ${ }^{+}$ $(30 / 0.5 / 0.5 \mathrm{mM})$, expressed in $\mathrm{nmol}_{2}(\mathrm{mg} \text { protein })^{-1} \mathrm{~min}^{-1}$. Values in parentheses indicate percent of control values. Dic indicates dichromate.

not directly evaluated because of technical difficulties. Ubiquinol-cytochrome $c$ reductase (complex III), catalyzing the electron flow from ubiquinol to cytochrome $c$, is a common pathway for respiration of exogenous
$\mathrm{NADH}$, succinate, and malate. Thus, in turnip mitochondria, the insensitivity of ubiquinol-cytochrome c reductase (complex III) to $\mathrm{Cr}(\mathrm{VI})$ was inferred by analyzing $\mathrm{O}_{2}$ consumption of mitochondria respiring
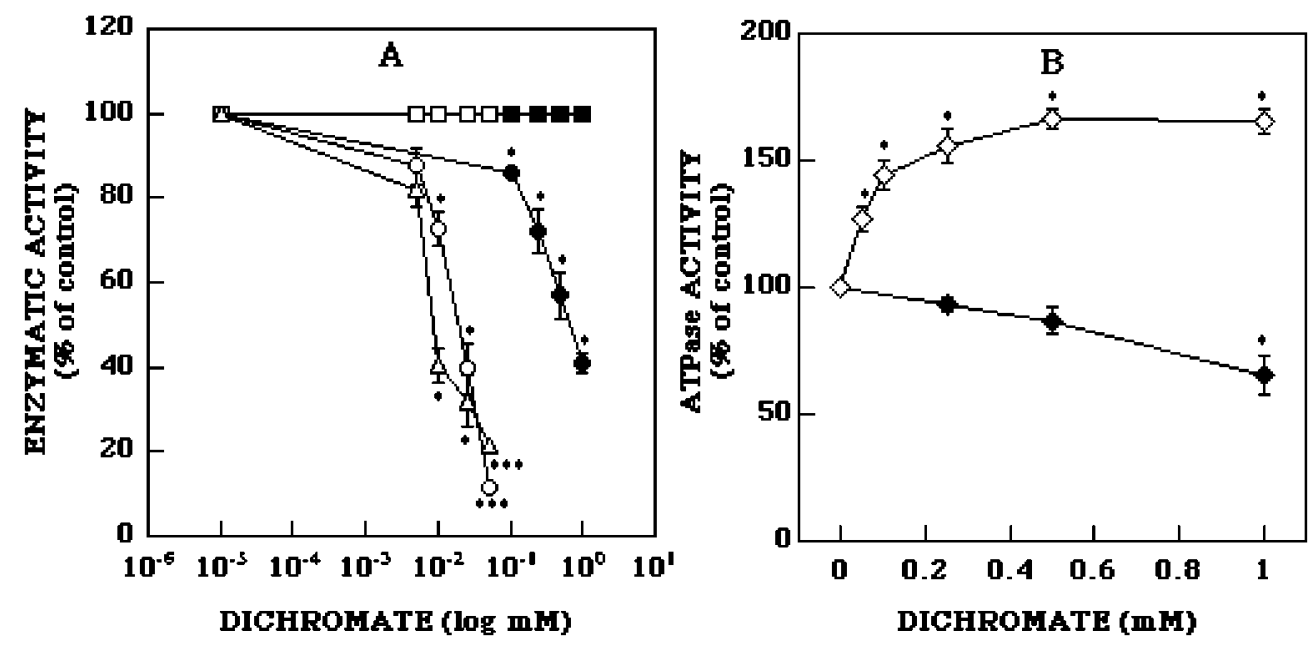

FIGURE 4. Effects of dichromate on the enzymatic activities of the turnip (full symbols) and rat (open symbols) (A) mitochondrial NADHubiquinone oxidoreductase $(\triangle)$, succinate-dehydrogenase (circles), cytochrome $c$ oxidase (squares) and (B) ATPase $(\downarrow$ and $\diamond)$. The results are expressed as percentage of control (\% of control). In rat mitochondria, control value for NADH-ubiquinone-oxidoreductase $=43 \pm 3.1 \mathrm{nmol}$ $\mathrm{NADH}$ oxidized (mg protein) $)^{-1} \mathrm{~min}^{-1}$ and for succinate dehydrogenase $=41 \pm 4.0 \mathrm{O}_{2}$ consumed (mg protein) ${ }^{-1} \mathrm{~min}^{-1}$. In turnip mitochondria, control value for succinate dehydrogenase $=282.5 \pm 4.0 \mathrm{O}_{2}$ consumed (mg protein $)^{-1} \mathrm{~min}^{-1}$. Control values of cytochrome $c$ oxidase were $368 \pm$ 4 for turnip and $335 \pm 10$ for rat, expressed as nmol oxidized cytochrome c. (mg protein) ${ }^{-1} \mathrm{~min}^{-1}$. Control values of ATPase activity were $38.8 \pm$ 5.1 for turnip and $36.2 \pm 3.1$ for rat, expressed as nmol Pi (mg protein $)^{-1} \mathrm{~min}^{-1}$. The results correspond to mean $\pm \mathrm{SE}$ of four to six independent experiments (when the error bars are not visible SE is encompassed by the size of the symbols). ${ }^{*} p<0.05$ for paired $t$ test when compared with the control (in the absence of dichromate). 
exogenous NADH (Figure 3). The ATPase activity was stimulated in rat liver, but inhibited in turnip root mitochondria (Figure 4B).

\section{Effects of Dichromate on Mitochondrial Membrane Potential and Permeability}

Dichromate affects the membrane potential $(\Delta \Psi)$ developed by succinate-supported respiration in the presence and absence of ADP (Figures 5A and 5B). $\Delta \Psi$ was fully collapsed in a period of several minutes. Depression of $\Delta \Psi$ induced by dichromate is more pronounced in rat liver mitochondria, as compared to turnip root mitochondria. In contrast, the phosphorylation was slowed down by dichromate more extensively for turnip than for rat mitochondria (Figures $5 \mathrm{~A}$ and 5B). Partial dissipation of turnip $\Delta \Psi$, by the action of the classical protonophore dinitrophenol (DNP-30 $\mu \mathrm{M}$ ), to values lower than those induced by $\mathrm{Cr}(\mathrm{VI})$, had a comparatively smaller effect on the ADP phosphorylation rate (Figure 5A1), suggesting that the $\mathrm{Cr}(\mathrm{VI})$-induced decrease of phosphosphorylation rate in turnip root mitochondria is related to phenomena in additional to $\Delta \Psi$ dissipation, i. e. concerning the ATP-synthase complex.

Mitochondrial passive swelling dependent on $\mathrm{H}^{+}$ and $\mathrm{K}^{+}$were studied for evaluation of dichromate effects on turnip root and rat liver mitochondrial membrane permeabilization (Figures 6 and 7). Permeabilization to $\mathrm{H}^{+}$was probed in a medium of potassium acetate, in the presence of $0.1 \%$ BSA, which prevents dissipation of the proton gradient by putative endogenous factors [46]. Maximum valinomycindependent swelling was observed after addition of the protonophore FCCP $(1 \mu \mathrm{M})$. FCCP was used to drive $\mathrm{H}^{+}$outside in exchange with $\mathrm{K}^{+}$influx. The excess of outside $\mathrm{H}^{+}$results in acetate protonation which can now cross the membrane. The overall effect is the accumulation of potassium acetate in the matrix, dependent on $\mathrm{H}^{+}$translocation, causing osmotic swelling. Dichromate up to $1 \mathrm{mM}$, at variance with FCCP, did not affect valinomycin-dependent mitochondrial swelling

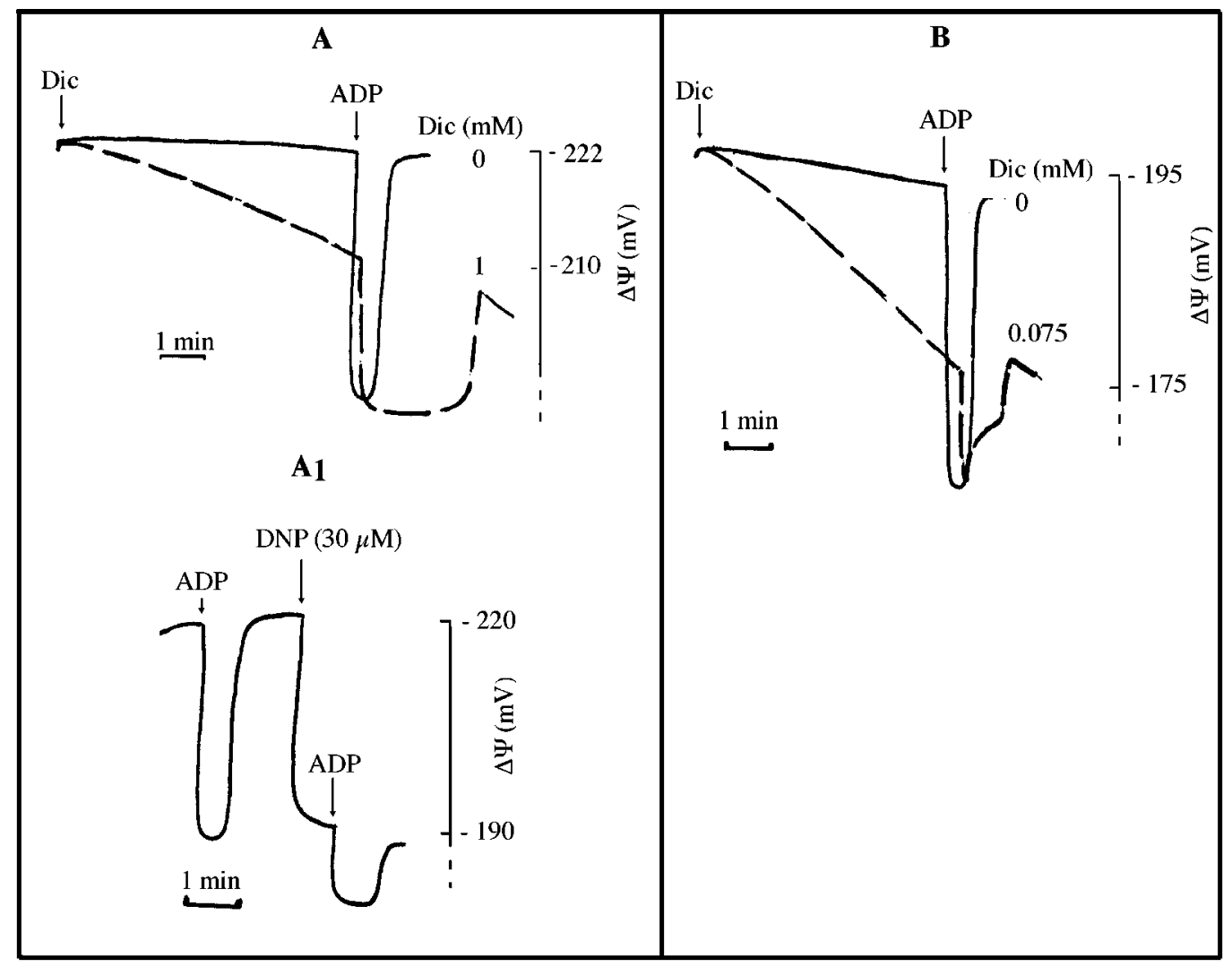

FIGURE 5. Time-dependent effects of dichromate on the mitochondrial transmembrane potential $(\Delta \Psi)$ and phosphorylation efficiency of (A) turnip and (B) rat mitochondria energized with succinate. (A1) turnip mitochondrial phosphorylation after partial $\Delta \Psi$ dissipation by dinitrophenol (DNP) as a reference, for the evaluation of dichromate effects. Turnip (0.3-0.4 mg of protein) or rat mitochondria (1-2 mg of protein) were preincubated in $1.5 \mathrm{~mL}$ standard respiratory medium and energized with $10 \mathrm{mM}$ succinate. Dichromate (Dic), at the indicated concentrations, was added 2.0-2.5 min after mitochondrial energization. ADP (200 $\mu \mathrm{M})$ was added after dichromate addition, where indicated. The traces represent typical direct recordings from six independent experiments with different mitochondrial preparations. 

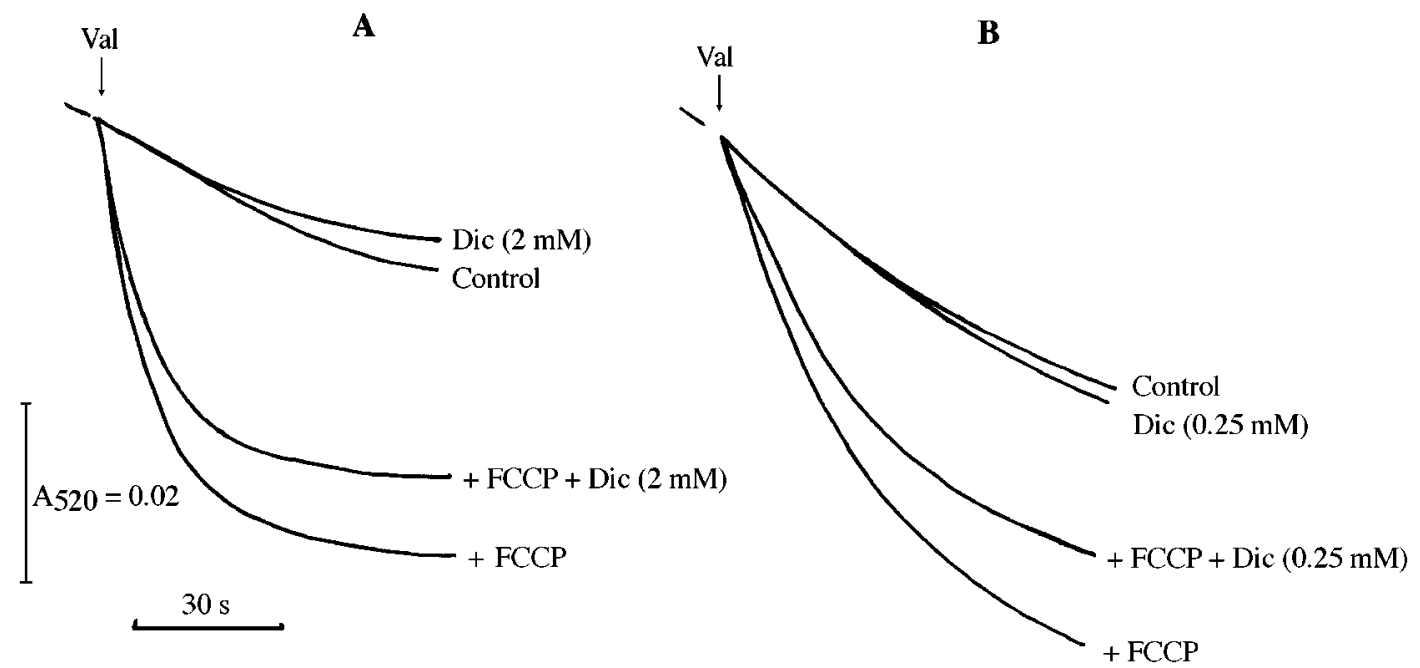

FIGURE 6. Effects of dichromate on the passive swelling of (A) turnip root mitochondria and (B) rat liver mitochondria, in potassium acetate medium. Turnip $(0.6 \mathrm{mg})$ or rat mitochondria $(1.5 \mathrm{mg})$ were suspended in $2.5 \mathrm{~mL}$ of $54 \mathrm{mM}$ potassium acetate, $5 \mathrm{mM} \mathrm{Hepes}(\mathrm{pH} 7.1), 0.2 \mathrm{mM}$ EDTA, $0.1 \mathrm{mM}$ EGTA, and $0.1 \%$ BSA at $25^{\circ} \mathrm{C}$. FCCP $(1 \mu \mathrm{M})$ or dichromate were added after $30 \mathrm{~s}$ incubation, and valinomycin $(1 \mu \mathrm{M})$ was added after $50 \mathrm{~s}$ incubation. Val, indicates addition of valinomycin, and Dic, addition of dichromate. Depicted curves are representative of at least three independent experiments with different mitochondrial preparations.

in plant and animal mitochondria (Figures 6A and $6 \mathrm{~B}$, respectively), indicating that $\mathrm{Cr}(\mathrm{VI})$ does not increase the proton conductance of the inner mitochondrial membrane.

Potassium succinate medium was used to probe the permeabilization to $\mathrm{K}^{+}$. Swelling dependent on respiration was observed by adding valinomycin, being the swelling observed only in conditions of $\mathrm{K}^{+}$influx. In the absence of valinomycin, dichromate induced mitochondrial swelling in plant and animal mitochondria, as a function of concentration (Figures 7A and 7C). This effect, inhibited by antimycin A (Figure 7B), is more pronounced in turnip, as compared to rat mitochondria. Clearly, these data are a consequence of mitochondrial membrane permeabilization to $\mathrm{K}^{+}$, induced by $\mathrm{Cr}(\mathrm{VI})$. The negative antimycin effect is putatively not related with $\mathrm{K}^{+}$permeabilization, but a consequence of blocking the $\mathrm{H}^{+}$pumps required to drive $\mathrm{K}^{+}$inside resulting in accumulation of potassium succinate in the matrix.

The effect of dichromate on mitochondrial membrane lipid peroxidation was assayed by measuring TBARS, attempting to devise putative mechanisms underlying the membrane permeabilization to $\mathrm{K}^{+}$. Lipid peroxidation was negligible at the end of incubation for $1 \mathrm{~h}$, thus discarding oxidative damage by lipid peroxidation as a putative process involved in the toxicity of $\mathrm{Cr}(\mathrm{VI})$ on mitochondria.

It must be pointed out that the sensitivity of turnip root and rat liver mitochondria to $\mathrm{Cr}(\mathrm{VI})$ is significantly different among preparations, specially for rat mitochondria.

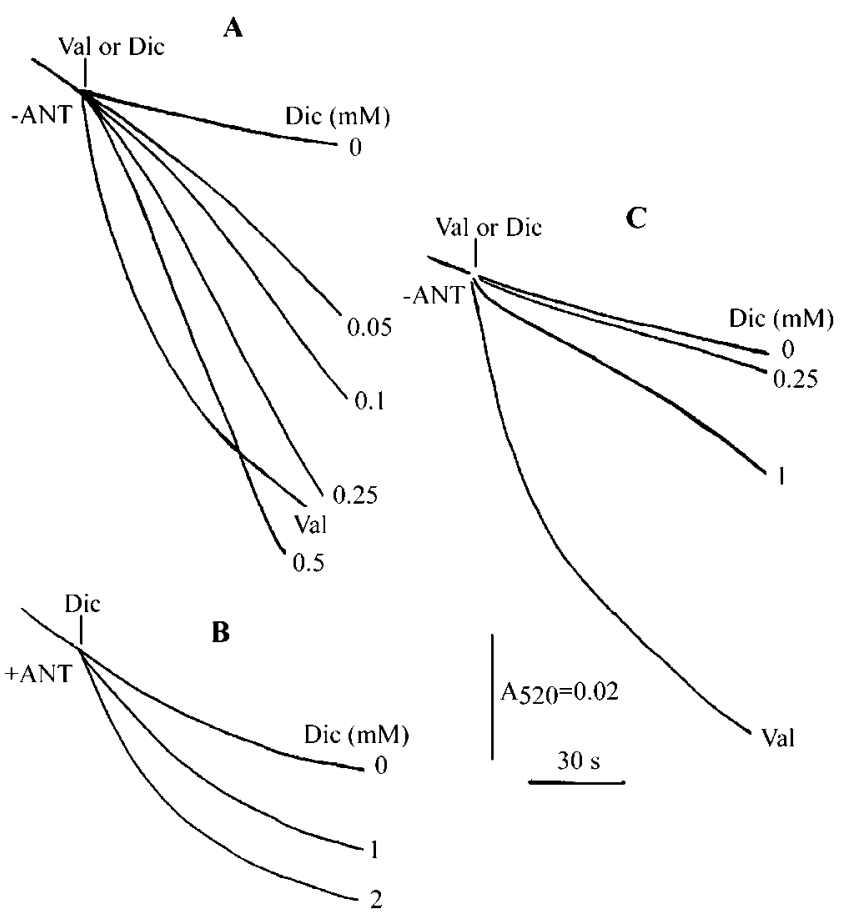

FIGURE 7. Effects of dichromate on the mitochondrial respiration supported swelling of turnip in the (A) absence, (B) presence of antimycin $\mathrm{A}$, and $(\mathrm{C})$ in rat in the absence of antimycin $\mathrm{A}$, in potassium succinate medium. Turnip $(0.6 \mathrm{mg})$ or rat mitochondria $(1.5$ $\mathrm{mg}$ ) were suspended in $2.5 \mathrm{~mL}$ of $54 \mathrm{mM}$ potassium succinate, $5 \mathrm{mM}$ Hepes (pH 7.1), $0.2 \mathrm{mM}$ EDTA, $0.1 \mathrm{mM}$ EGTA, and $0.1 \%$ BSA at $25^{\circ} \mathrm{C}$. When required, $1 \mu \mathrm{M}$ antimycin $\mathrm{A}$ was added (+ANT) to the reaction medium. - ANT, indicates the absence of antimycin A in the reaction medium. Dichromate (Dic) or $1 \mu \mathrm{M}$ valinomycin (Val) were added after $50 \mathrm{~s}$ incubation. Depicted curves are representative of at least three independent experiments with different mitochondrial preparations. 


\section{DISCUSSION}

Chromium(VI) interferes with plant and animal mitochondrial bioenergetics as a function of concentration and exposure time, independently of mitochondrial membane damage induced by oxidative stress. However, differences in the sensitivity to $\mathrm{Cr}(\mathrm{VI}), \Delta \Psi$ and phosphorylation efficiency, state 4 respiration and ATPase activities, and $\mathrm{K}^{+}$influx were detected between plant and animal mitochondria.

Chromium(VI) interference with mitochondrial bionergetics was shown: decrease of the succinatedependent respiratory indexes, (RCR and ADP/O) (Figure 1); inhibition of oxygen-supported respiration by succinate or malate in state 3 and uncoupled respiration (Figures 2, 3, and Table 1, respectively) with parallel $\Delta \Psi$ dissipation (Figure 5) and decrease of the phosphorylation efficiency (Figure 5); inhibition of the NADH-ubiquinone oxidoreductase (complex I) and succinate-dehydrogenase (complex II) (Figure 4); alterations in the mitochondrial ATPase activity (complex V) (Figure 4); and membrane permeabilization to $\mathrm{K}^{+}$(Figure 7). Based on these findings, it can be concluded that $\mathrm{Cr}(\mathrm{VI})$ interferes with mitochondrial bioenergetics by inducing perturbations in complex I and complex II of the electron transport system, phosphorylation system (complex V), and membrane permeabilization to $\mathrm{K}^{+}$. Other reports on the mitochondrial respiration argue that inhibitory effects of $\mathrm{Cr}(\mathrm{VI})$ were coupled to $\mathrm{Cr}(\mathrm{VI})$ reduction by the mitochondrial electron transport [16,17], at the levels of complex I [24-26], complex II $[19,26,27]$, and complex IV [26]. This last effect is negated by our data clearly indicating insensitivity of complex IV to Cr(VI) (Figure 4). The ubiquinolcytochrome $c$ reductase (complex III) (Figure 3) and membrane permeabilization to $\mathrm{H}^{+}$(Figure 6) were also insensitive to $\mathrm{Cr}(\mathrm{VI})$.

Animal mitochondria respiration was more sensitive to $\mathrm{Cr}(\mathrm{VI})$ than plant mitochondria, as shown by the different $\mathrm{Cr}(\mathrm{VI})$ concentration ranges inducing similar alterations on mitochondrial $\mathrm{O}_{2}$ consumption (Figures 1, 2, 4, and Table 1), $\Delta \Psi$, and phosphorylation efficiency developed by succinate-supported respiration (Figure 5). The higher sensitivities of rat mitochondria to $\mathrm{Cr}(\mathrm{VI})$ as compared with turnip mitochondria may reflect the sensitivity of complex I and complex II of the mitochondrial respiratory system (Figure 4 and Table 1). The inhibitory action of $\mathrm{Cr}(\mathrm{VI})$ on the activity of the succinate-dependent respiration observed for turnip and rat mitochondria (Figure 4) is in agreement with data published by others with cultured J774A.1 macrophage cells [47] and cultured human gingival fibroblasts [21]. However, the inhibitory action of $\mathrm{Cr}(\mathrm{VI})$ on the activity of NADH-ubiquinone oxidoreductase in rat mitochondria (Figure 4) is at variance with the stimulatory action described for cultured human gingival fibroblasts [21].

The higher sensitivity of complex II to $\mathrm{Cr}(\mathrm{VI})$ of rat mitochondria, as compared with turnip mitochondria, also supports the different data concerning $\mathrm{Cr}(\mathrm{VI})$ induced dissipation of succinate-supported $\Delta \Psi$ in rat and turnip mitochondria (Figure 5). However, it did not explain the accentuated decrease in the phosphorylation efficiency of turnip mitochondria (Figure 5). This effect cannot also be explained by $\Delta \Psi$ dissipation by $\mathrm{H}^{+}$ leak, since permeabilization to $\mathrm{H}^{+}$in turnip mitochondrial membrane is insensitive to $\mathrm{Cr}(\mathrm{VI})$ (Figure 6). Also, induction of partial $\Delta \Psi$ dissipation with the classical protonophore dinitrophenol to values lower than those induced by $\mathrm{Cr}(\mathrm{VI})$ had a comparativelly smaller effect on the ADP phosphorylation (Figure 5). Alternatively, the decrease in the phosphorylation efficiency of turnip may be explained by the decrease of the ATP-synthase as reflected by a partial inhibition of the ATPase activity (Figure 4).

Another important difference for the $\mathrm{Cr}(\mathrm{VI})$ effects on rat and turnip mitochondria was detected in the state 4 respiration. Chromium(VI) stimulated the state 4 respiration- supported by succinate in rat mitochondria, but had no significant effect in turnip mitochondria (Figure 2). State 4 respiration is controlled by the proton leak across the inner mitochondrial membrane [48]. Since permeabilization to $\mathrm{H}^{+}$in rat mitochondrial membrane is insensitive to $\mathrm{Cr}(\mathrm{VI})$ (Figure 6), the increased $\mathrm{H}^{+}$leak is excluded. It may be explained by the increased ATPase activity (Figure 4). Stimulation of the ATP hydrolysis promotes an increased ADP/ATP turnover, which dissipates the proton motive force. Therefore, the $\mathrm{H}^{+}$pumps are stimulated and the respiration rate is potentiated. This explanation is supported by the findings showing the absence of a $\mathrm{Cr}(\mathrm{VI})$ effect on the ATPase of turnip mitochondria and the negligible stimulation of state 4 respiration (Figure 2).

The increased $\mathrm{K}^{+}$influx in turnip mitochondria, as compared with rat mitochondria, cannot be related with $\mathrm{Cr}(\mathrm{VI})$-induced mitochondrial membrane oxidative damage, as membrane lipid peroxidation was negligible. Although these findings discarded oxidative damage by lipid peroxidation as a putative process involved on $\mathrm{Cr}(\mathrm{VI})$-induced mitochondrial membrane permeabilization to $\mathrm{K}^{+}$, oxidative stress can not be excluded because the direct effect of $\mathrm{Cr}(\mathrm{VI})$ on ROS production by mitochondria was not evaluated.

In contrast with the $\mathrm{Cr}(\mathrm{VI})$ effect on $\mathrm{K}^{+}$influx (Figure 7), mitochondrial respiration is less affected by $\mathrm{Cr}(\mathrm{VI})$ in turnip than in rat mitochondria. Since $\mathrm{K}^{+}$influx is dependent on mitochondrial respiration (Figure 7), the different results concerning the $\mathrm{Cr}(\mathrm{VI})$ effect on the membrane permeabilization to $\mathrm{K}^{+}$may be 
a consequence of the different sensitivity of plant and animal mitochondrial respiration to $\mathrm{Cr}(\mathrm{VI})$.

In conclusion, although $\mathrm{Cr}(\mathrm{VI})$ interfers with mitochondrial bienergetics, important differences were detected for the $\mathrm{Cr}(\mathrm{VI})$ effects in plant and animal mitochondria. Chromium(VI)-induced perturbations on mitochondrial bioenergetics will compromise energydependent biochemical processes, and, therefore, may contribute to the basal mechanism underlying its toxic effects in plant and animal cells.

\section{ACKNOWLEDGMENT}

We are indebted to Dr. R. A. Videira for the preparation of rat liver mitochondria, and to Prof. A. J. $\mathrm{M}$. Moreno for several helpful suggestions during the work.

\section{REFERENCES}

1. Rowbotham AL, Levy LS, Shuker LK. Chromium in the environment: An evaluation of exposure of the UK general population and possible adverse health effects. J Toxicol Environ Health Part B 2000;3:145-178.

2. Barceloux DG. Chromium. Clin Toxicol 1999;37:173-194.

3. Stohs SJ, Bagchi D, Hassoun E, Bagchi M. Oxidative mechanisms in the toxicity of chromium and cadmium ions. J Environ Pathol Toxicol Oncol 2001;20:77-88.

4. Hauschild MZ. Putrescine (1,4-diaminobutane) as an indicator of pollution-induced stress in higher plants: Barley and rape stressed with $\mathrm{Cr}(\mathrm{III})$ or $\mathrm{Cr}(\mathrm{VI})$. Ecotoxicol Environ Saf 1993;26:228-247.

5. Chatterjee J, Chatterjee C. Phytotoxicity of cobalt, chromium and copper in cauliflower. Environ Pollut 2000;109:69-74.

6. Appenroth KJ, Stöckel J, Srivastava A, Strasser RJ. Multiple effects of chromate on the photosynthetic apparatus of Spirodela polyrhiza as probed by OJIP chlorophyll a fluorescence measurements. Environ Pollut 2001;115:49-64.

7. Shi X, Chiu A, Chen CT, Halliwell B, Castranova V, Vallyathan V. Reduction of chromium(VI) and its relationship to carcinogenesis. J Toxicol Environ Health Part B, 1999;2:87-104.

8. Shi X, Dong Z, Huang C, Ma W, Liu K, Ye J, Chen F, Leonard SS, Ding M, Castranova V, Vallyathan V. The role of hydroxyl radical as a messenger in the activation of nuclear transcription factor NF-kB. Mol Cell Biochem 1999;194:63-70.

9. Ye J, Wang S, Leonard SS, Sun Y, Butterworth L, Antonini J, Ding M, Rojanasakul Y, Vallyathan V, Castranova V, Shi X. Role of reactive oxygen species and p53 in chromium(VI)-induced apoptosis. J Biol Chem 1999;274:34974-34980.

10. Wang S, Leonard SS, Ye J, Ding M, Shi X. The role of hydroxyl radical as a messenger in $\mathrm{Cr}(\mathrm{VI})$-induced p53 activation. Am J Physiol Cell Physiol 2000;279:C868-C875.

11. Zang Z, Leonard SS, Wang SW, Vallyathan V, Castranova $\mathrm{V}$, Shi X. Cr(VI) induces cell growth arrest through hydrogen peroxide-mediated reactions. Mol Cell Biochem 2001;222:77-83.
12. Qian $Y$, Jiang B-H, Flynn DC, Leonard SS, Wang S, Zhang Z, Ye J, Chen F, Wang L, Shi X. Cr(VI) increases tyrosine phosphorylation through reactive oxygen speciesmediated reactions. Mol Cell Biochem 2001;222:199_ 204.

13. Liu KJ, Jiang J, Shi $X$, Gabrys H, Walczak T, Swartz HM. Low-frequency EPR study of chromium(V) formation from chromium(VI) in living plants Biochem Biophys Res Commun 1995;206:829-834.

14. Appenroth KJ, Bischoff M, Gabrys H, Stoeckel J, Swartz HM, Walczak T, Winnefeld K. Kinetics of chromium(V) formation and reduction in fronds of the duckweed of Spirodela polyrhiza-a low frequency EPR study. J Inorg Biochem 2000;78:235-242.

15. Palmeira $\mathrm{CM}$, Moreno $\mathrm{AJ}$, Madeira VMC. Interactions of herbicides 2,4-D and dinoseb with liver mitochondrial bioenergetics. Toxicol Appl Pharmacol 1994;127:5057.

16. Debetto P, Dal Toso $R$, Varotto R, Bianchi V, Luciani S. Effects of potassium dichromate on ATP content of mammalian cells cultured in vitro. Chem Biol Interact 1982;41:15-24.

17. Bianchi V, Debetto P, Zantedeschi A, Levis AG. Effects of hexavalent chromium on the adenylate pool of hamster fibroblasts. Toxicology 1982;25:19-30.

18. Bumgardner JD, Doeller J, Lucas LC. Effect of nickelbased dental casting alloys on fibroblast metabolism and ultrastructural organization. J Biomed Mater Res 1995;29:611-700.

19. Messer RLW, Doeller JE, Kraus DW, Lucas LC. An investigation of fibroblast mitochondria enzyme activity and respiration in response to metallic ions released from dental alloys. J Biomed Mater Res 2000;50:598-604.

20. Messer R, Lucas LC. Evaluation of metabolic activities as biocompatibility tools: A study of individual ions' effects on fibroblasts. Dent Mater 1999;15:1-6.

21. Messer RL, and Lucas LC. Cytotoxicity of nickelchromium alloys: Bulk alloys compared to multiple ion salt solutions. Dent Mater 2000;16,207-212.

22. Lazzarini A, Luciani S, Beltrame M, Arslan P. Effects of chromium(VI) and chromium(III) on energy charge and oxygen consumption in rat thymocytes. Chem Biol Interact 1985;53:273-281.

23. Granchi D, Ciapetti G, Savarino L, Cavedagna D, Donati ME, Pizzoferrato A. Assessment of metal extract toxicity on human lymphocytes cultured in vitro. J Biomed Mater Res 1996;31:183-191.

24. Ryberg D, Alexander J. Inhibitory action of hexavalent chromium $(\mathrm{Cr}(\mathrm{VI}))$ on the mitochondrial respiration and a possible coupling to the reduction of $\mathrm{Cr}(\mathrm{VI})$. Biochem Pharmacol 1984;33:2461-2466.

25. Ryberg D, Alexander J. Mechanisms of chromium toxicity in mitochondria, Chem Biol Interact 1990;75:141-151.

26. Rossi SC, Wetterhahn KE. Chromium(V) is produced upon reduction of chromate by mitochondrial electron transport chain complexes. Carcinogenesis 1989;10:913920.

27. Arillo A, Melodia F, Frache R. Reduction of hexavalent chromium by mitochondria: Methodological implications and possible mechanisms. Ecotoxicol Environ Saf 1987;164-177.

28. Shi X, Dalal NS, Vallyathan V. One-electron reduction of carcinogen chromate by microsomes, mitochondria, and Escherichia coli: Identification of $\mathrm{Cr}(\mathrm{V})$ and $\mathrm{OH}$ radical. Arch Biochem Biophys 1991;290:381-386. 
29. Bagchi D, Vuchetich PJ, Bagchi M, Hassoun EA, Tran MX, Tang L, Stohs SJ. Induction of oxidative stress by chronic administration of sodium dichromate [chromium VI] and cadmium chloride [cadmium II] to rats. Free Radic Biol Med 1997;22:471-478.

30. Travacio M, Polo JM, Llesuy S. Chromium(VI) induces oxidative stress in the mouse brain. Toxicology 2000;150:137-146.

31. Moller IM, Lin W. Membrane-bound NAD(P)H dehydrogenases in higher plant cells. Ann Rev Plant Physiol Plant Mol Biol 1986;37:309-334.

32. Douce R, Neuburger M. The uniqueness of plant mitochondria. Ann Rev Plant Physiol Plant Mol Biol 1989;40:371-414.

33. Ernster L, Nordenbrand K. Microsomal lipid peroxidation. In: Colowick SP, Kaplan NO, editors. Methods in Enzymology. New York: Academic Press; 1967. Vol. 10, pp. 574-580.

34. Vicente JAF, Madeira VMC. The excellence of turnip mitochondrial fractions. Biochem Educ 2000;28:104-106.

35. Gazotti P, Malmstron K, Crompton MA. Laboratory manual on transport and bioenergetics. In: Carafoli E, Semenza G, editors. Membrane Biochemistry. New York: Springer-Verlag; 1979. pp 62-69.

36. Gornall AG, Bardawill CG, David MM. Determination of serum proteins by means of the biuret reaction. J Biol Chem 1949;177:751-766.

37. Chance B, Williams GR. The respiratory chain and oxidative phosphorylation. Adv Enzymol 1956;17:65-134.

38. Ragan CI, Wilson MT, Darley-Usmar VM, Lowe PN. Sub-fractionation of mitochondria and isolation of the proteins of oxidative phosphorylation. In: Darley-Usmar VM, Rickwood D, Wilson MT, editors. Mitochondria: A Pratical Approach. Oxford: IRL Press; 1987. pp 79112.
39. Singer TP. Determination of the activity of succinate, $\mathrm{NADH}$, choline and glycerophosphate dehydrogenases. Methods Biochem Anal 1974;22:123-175.

40. Wharton DC, Tzagoloff A. Cytochrome oxidase from beef heart mitochondria. In: Colowick SP, Kaplan NO, editors. Methods in Enzymology. New York: Academic Press; 1967. pp 245-250.

41. Taussky HH, Shorr E. A microcolorimetric method for the determination of inorganic phosphorus. J Biol Chem 1953;202:675-685.

42. Kamo N, Muratsugu M, Hongoh R, Kobatake N. Membrane potential of mitochondria measured with an electrode sensitive to tetraphenylphosphonium and relationship between proton electrochemical potential and phosphorylation potential in steady state. J Membr Biol 1979;49:105-121.

43. Vicente JAF, Santos MS, Vercesi AE, Madeira VMC. Comparative effects of the herbicide dinitro-o-cresol on mitochondrial bioenergetics. Pestic Sci 1998;54:43-51.

44. Mahan BM, Myers RJ. In: Hunter D, Brown D, editors. University Chemistry. 3rd edition. Menlo Park: Bengamin/Cummings; 1987. pp.834-836.

45. Connett PH, Wetterhahn KE. Metabolism of carcinogenic chromate. Struct Bond 1983;54:93-124.

46. Vercesi A, Martins IS, Silva MAP, Leite HMF, Cuccovia IM, Chimovich H. Pumping plants. Nature (London) 1995;24.

47. Bagchi D, Tran MX, Newton M, Bagchi M, Ray SD, Kuszynski CA, Stohs SJ. Chromium and cadmium induced oxidative stress and apoptosis in cultured J774A.1 macrophage cells. In Vitro. Mol Toxicol 1998;11:171-181.

48. Brand MD, Hafner RP, Brown GC. Control of respiration in non-phosphorylating mitochondria is shared between the proton leak and the respiratory chain. Biochem J 1988;255:535-539. 